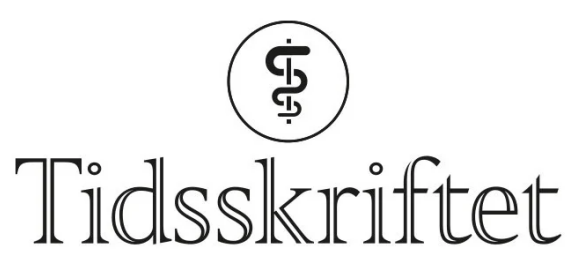

DEN NORSKE LEGEFORENING

\title{
Bitt av veggedyr
}

\author{
MEDISINEN I BILDER
}

\section{OLAV ROGDE GRAMSTAD}

olgram@ous-hf.no

Olav Rogde Gramstad er lege i spesialisering og konstituert overlege ved Seksjon for hudsykdommer ved Oslo universitetssykehus, Rikshospitalet.

Forfatteren har fylt ut ICMJE-skjemaet og oppgir ingen interessekonflikter.

\section{SYED MOHAMMAD HUSAIN RIZV}

Syed Mohammad Husain Rizvi er ph.d., spesialist i hud- og veneriske sykdommer og overlege ved Seksjon for hudsykdommer ved Oslo universitetssykehus, Rikshospitalet.

Forfatteren har fylt ut ICMJE-skjemaet og oppgir ingen interessekonflikter.

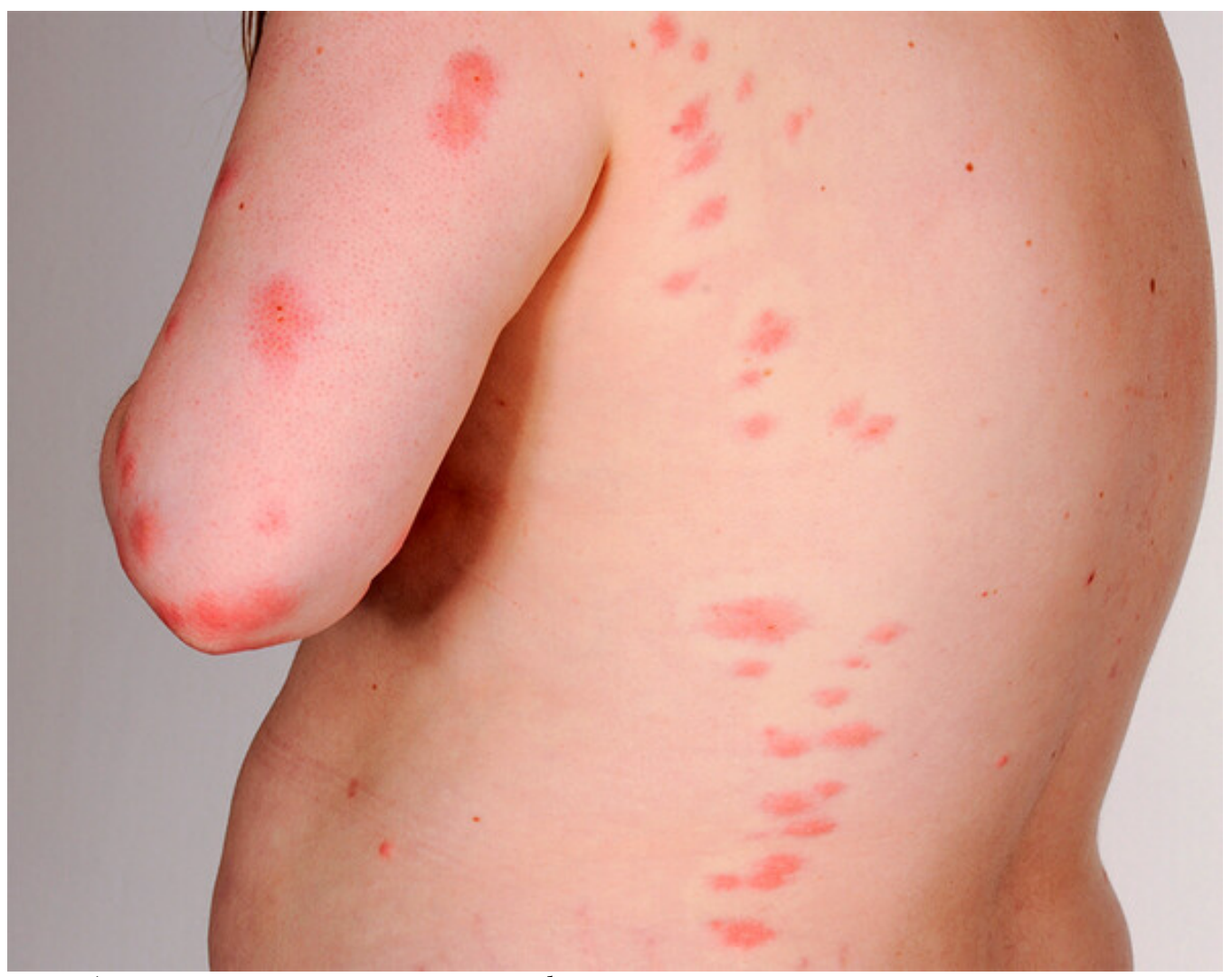

Foto: Øystein Horgmo, Universitetet i Oslo 
Bildet viser et symmetrisk utslett med lineært distribuerte rødrosa papler og kvadler på armer og flanker som følge av veggedyrbitt. Ryggen er utspart fordi pasienten har sovet $\mathrm{i}$ ryggleie.

Pasienten, en frisk student, flyttet til en ferdigmøblert leilighet på sommerstid. Den første kvelden, noen timer etter leggetid, begynte det å klø, og pasienten utviklet raskt et generalisert utslett. Lokal legevakt ble oppsøkt akutt, og utslettet ble ved ankomst oppfattet som elveblest. Grunnet utbredt utslett og stor symptombyrde ble pasienten lagt inn til observasjon, og man startet behandling med prednisolon $40 \mathrm{mg} / \mathrm{dag}$ samt cetirizin $10 \mathrm{mg} / \mathrm{dag}$. Pasienten ble drøftet med vakthavende hudlege og tilsett ved hudpoliklinikken neste dag. Utslettet var da som på bildet og vurdert som karakteristisk for insektbitt.

Pasienten var afebril, og blodprøver viste leukocytter 17,6 $\times 10^{9} / \mathrm{L}$ (referanseområde 3,5-10 $\times$ $\left.10^{9}\right)$, nøytrofile granulocytter $15,5 \times 10^{9} / \mathrm{L}\left(1,5-7,3 \times 10^{9}\right)$ og CRP $32 \mathrm{mg} / \mathrm{L}(<4)$.

Et skadedyrfirma befarte leiligheten og bekreftet veggedyrinfestasjon. Pasienten sov annensteds mens saneringstiltak ble gjennomført. Prednisolonbehandlingen ble trappet gradvis ned over to uker, mens cetirizindosen forble uendret inntil behandlingen ble avsluttet ved kontroll to uker etter behandlingsstart. Ved kontrollen fantes intet utslett foruten postinflammatorisk hyperpigmenterte områder.

Veggedyr (Cimex lectularius) er vingeløse insekter som lever av blod fra varmblodige dyr. De er rødbrune, inntil 6-7 mm lange, med flat, oval kroppsfasong (1). Veggedyrene lever skjult i sprekker og hulrom i senger, sofaer o.l. Om natten forlater de skjulestedet midlertidig for å suge blod fra eksponert hud hos den sovende verten. Vertens sovestilling og tildekning er derfor avgjørende for utslettets distribusjon. I de angrepne hudområdene finnes grupperte eller enslige kløende røde makler, papler eller kvadler i et lineært mønster. Det er stor individuell symptomvariasjon (므).

Utslett og kløe etter bitt kan vanligvis behandles med antihistaminer og lokale steroider. Systemiske steroider er sjelden nødvendig. Veggedyr kan leve lenge uten mat, være resistente mot insektmidler og forflytte seg mellom rom og leiligheter. Sanering kan være krevende, og det er ofte nødvendig med bistand fra profesjonelle skadedyrfirma (3).

Pasienten har gitt samtykke til at artikkelen blir publisert. Artikkelen er fagfellevurdert.

\section{LITTERATUR}

1. Harlan HJ. Bed Bugs 101: the Basics of Cimex lectularius. Am Entomol (Lanham Md) 2006; 52: 99-101. [CrossRef]

2. Doggett SL, Dwyer DE, Peñas PF et al. Bed bugs: clinical relevance and control options. Clin Microbiol Rev 2012; 25: 164-92. [PubMed][CrossRef]

3. Folkehelseinstituttet. Veggedyr. https://www.fhi.no/nettpub/skadedyrveilederen/veggedyr-ogandre-teger/veggedyr/ Lest 7.9.2021.

Publisert: 8. november 2021. Tidsskr Nor Legeforen. DOI: 10.4045/tidsskr.21.0505

Mottatt 18.6.2021, første revisjon innsendt 10.9.2021, godkjent 27.9.2021.

(C) Tidsskrift for Den norske legeforening 2023. Lastet ned fra tidsskriftet.no 26. april 2023. 